\title{
Fixed-term contracts and wages revisited using linked employer-employee data
}

\author{
Christian Pfeifer
}

Accepted: 4 May 2012 / Published online: 3 July 2012

(C) Institut für Arbeitsmarkt- und Berufsforschung 2012

\begin{abstract}
This empirical research note uses linked employeremployee data from the German Federal Statistical Office to estimate wage differentials between workers with fixedterm contracts and permanent contracts. The data set allows to analyze wage differentials within firms and across the wage distribution. The main findings are: (1) Worker characteristics account for about half of the unconditional mean wage differential. The wage disadvantage of workers with fixed-term contracts is further reduced by the inclusion of occupations and firm fixed effects to approximately ten percent. (2) The wage disadvantage is larger at the lower tail of the wage distribution and quite constant in the middle and upper parts of the wage distribution.
\end{abstract}

Keywords Dual internal labor market · Fixed-term contract · Linked employer-employee data · Wage differential · Wage distribution

\section{JEL Classification $\mathrm{J} 31 \cdot \mathrm{J} 41$}

\section{Befristete Arbeitsverträge und Entlohnung neu untersucht mit verbundenen Arbeitgeber-Arbeitnehmer-Daten}

Zusammenfassung Dieser empirische Beitrag nutzt verbundene Arbeitgeber-Arbeitnehmer-Daten des Statistischen

Electronic supplementary material The online version of this article (doi:10.1007/s12651-012-0107-9) contains supplementary material, which is available to authorized users.

\section{Pfeifer $(\bowtie)$}

Institute of Economics, Leuphana University Lüneburg,

Scharnhorststr. 1, 21335 Lüneburg, Germany

e-mail: pfeifer@leuphana.de
Bundesamtes, um Lohndifferentiale zwischen Arbeitnehmern mit befristeten und unbefristeten Arbeitsverträgen zu schätzen. Der Datensatz erlaubt die Analyse der Lohndifferentiale innerhalb von Firmen und über die Lohnverteilung. Die wesentlichen Ergebnisse sind: (1) Unterschiede in den persönlichen Eigenschaften der Arbeitnehmer erklären etwa die Hälfte der unbedingten mittleren Lohndifferenz. Die geschätzten Lohnnachteile von Arbeitnehmern mit befristeten Arbeitsverträgen sinken durch die Aufnahme von Berufen und fixen Firmeneffekten auf ungefähr zehn Prozent. (2) Der Lohnnachteil ist größer am unteren Ende der Lohnverteilung und fast unverändert im mittleren und oberen Teil der Lohnverteilung.

Schlüsselwörter Dualer interner Arbeitsmarkt · Befristeter Arbeitsvertrag · Verbundene

Arbeitgeber-Arbeitnehmer-Daten · Lohndifferential ·

Lohnverteilung

\section{Introduction}

High unemployment and competitive pressure led to a call for labor market flexibility and to labor market reforms with respect to temporary employment in many European countries since the 1980s (OECD 2002, pp. 127-185; Gebel and Giesecke 2009; Pfeifer 2009). These reforms have made it easier for firms to employ workers on a temporary basis and increased the share of workers with temporary contracts, especially fixed-term contracts (FTCs). In Germany, for example, FTCs were highly regulated until the introduction of the Employment Promotion Act (,Beschäftigungsförderungsgesetz") in 1985. This legal change relaxed the former rule that the employer had to demonstrate the temporary nature of 
the work (e.g., by providing objective reasons such as seasonal fluctuations) and that FTCs had a maximum duration of only six months. The Employment Promotion Act of 1985 allowed a single FTC to last up to 18 months without justification if the employee was newly hired or if an apprentice could not be offered a regular job. In 1996, the duration of FTCs was raised to 24 months with three renewals possible within this period. If the contract was justified by an objective reason, the legal restrictions did not apply. In January 2001, the regulation of FTCs in Germany was again renewed and regulated in a single law (,Gesetz über Teilzeitarbeit und befristete Arbeitsverträge"). The new legislation includes the prohibition of discrimination at the workplace, which refers to equal pay and treatment. Such an equal pay policy seemed necessary due to the labor market segregation in good permanent jobs and bad temporary jobs.

Theoretical predictions about the wage effects of FTCs are contradictory. On the one hand, compensating wage theory predicts that temporary workers should receive, ceteris paribus, higher wages than permanent workers, because workers are usually risk averse so that they prefer permanent contracts and need to be compensated for FTCs. Dual (segmented) labor market theory, on the other hand, predicts that temporary workers have jobs in lower paying industries and firms (Taubman and Wachter 1986; Leontaridi 1998). In fact, even dual internal labor markets are very common, i.e., one firm employs a permanent (core) workforce as well as a temporary (peripheral) workforce (Rebitzer and Taylor 1991; Saint-Paul 1991; Pfeifer 2009). Whereas the former enjoys benefits of internal labor market structures (e.g., high wages, long-term stable employment, training, promotions), the latter is used as a flexible buffer to deal with demand shocks and has worse working conditions such as low wages. FTCs can also serve as stepping stones into internal labor markets in form of extended probation periods, during which the firm screens workers with uncertain quality (Booth et al. 2002; Güell and Petrongolo 2007; Boockmann and Hagen 2008). Workers are usually paid lower wages during probation and get a wage increase after being contracted permanently when satisfying the firm's hiring standards. In sum, the two rationales "compensating wage differentials" (wage premium for FTC) and "dual internal labor markets" (wage penalty for FTC) lead to opposing predictions.

Theoretical considerations about wage effects of FTCs across the wage distribution should also take into account workers' differences in labor market opportunities. If workers at the upper tail of the wage distribution have good labor market opportunities (e.g., labor supply shortage of highly qualified experts or successful managers), they might work voluntarily with FTCs and change firms more frequently to increase their wages during bargaining processes. Consequently, the wage differentials between workers with temporary and permanent contracts are likely to be small or even in favor of FTCs at the upper tail of the wage distribution. On the other hand, workers with bad labor market opportunities at the lower tail of the wage distribution (excess labor supply) are likely to suffer more from segregation. If their temporary employment does not allow them to enter internal labor markets, the wage penalties for FTCs at the lower tail of the wage distribution should be larger. Due to excess labor supply and larger quality uncertainty of workers with bad labor market opportunities, extended probation periods in form of FTCs are likely to be used more frequently, which should also lead to larger wage penalties for FTCs at the lower tail of the wage distribution.

From an empirical perspective, it is well established that workers with FTCs earn on average significant lower wages than workers with permanent contracts (e.g., Booth et al. 2002; Hagen 2002; OECD 2002, pp. 141-144; Brown and Sessions 2003, 2005; Mertens and McGinnity 2004, 2005; Mertens et al. 2007). Some studies also explore the wage differentials across the wage distribution and find larger than average wage differentials at the lower tail of the wage distribution and low but still significant wage disadvantages for FTCs at the top of the wage distribution (Mertens and McGinnity 2005; Mertens et al. 2007). Due to data limitations previous studies, at least for Germany, suffer from several shortcomings. While household survey data such as the GSOEP (German Socio-Economic Panel) contain information about FTCs and worker characteristics, they do not comprise information about a worker's workplace so that within-firm wage differentials cannot be estimated. Consequently, the estimated wage differentials might suffer from an omitted variable bias due to unobserved firm characteristics. If, for example, FTCs are more likely to be employed by low wage firms, which also pay workers with permanent contracts low wages, the within-firm wage differential should be smaller than the wage differential across low and high wage firms. In order to deal with this issue, linked employer-employee data are necessary. Unfortunately, the linked employer-employee data set of the IAB (LIAB), which is often used to analyze the German labor market because it contains a large number of firms with their total workforce and many firm characteristics, does not contain information about a worker's contract type. Therefore, I use an administrative linked employer-employee data set from the German Federal Statistical Office- the German Structure of Earnings Survey 2006. Due to its large sample size, the German Structure of Earnings Survey is also more suitable to analyze the wage differentials across the wage distribution than smaller survey data sets.

The remainder of the paper is structured as follows. The next section informs about the German Structure of Earn- 
ings Survey, sample restrictions, variables, and the estimation strategies. Section 3 presents the estimated wage differentials between workers with FTCs and permanent contracts. The paper concludes with a short summary in Sect. 4 .

\section{Data and estimation strategies}

The used linked employer-employee data set is the scientific use file of the German Structure of Earnings Survey of the year 2006 (October), which is constructed by the German Federal Statistical Office (Hafner and Lenz 2008). ${ }^{1}$ The data comprise information about more than three million workers in about 34,000 firms with at least ten workers across all industries and federal states. Because information for firms from the education sector (NACE M) is obtained from personnel statistics and partly approximated, no individual wages for workers are available and these firms are not considered in the analysis. ${ }^{2}$ Firms from other industries are randomly selected and the sample is stratified according to region, industry, and firm size. The response of the questionnaires is mandatory for the selected firms. In firms with less than 50 workers information about the complete workforce is demanded, whereas a random sample of workers is drawn in larger firms.

I restrict the sample to workers aged between 18 and 65 years, who are not apprentices, marginal workers, civil servants, or in partial retirement. Moreover, sample restrictions are imposed with respect to the number of observations within each firm. The generated sample contains all firms and their workers, if the firm has, according to the above sample restrictions, at least twenty workers in the sample, of whom at least two have FTCs and at least two have permanent contracts. This restriction is necessary in order to make comparisons between workers with FTCs and permanent contracts meaningful at the firm-level, because it abets that comparable workers exists in one firm (e.g., good educated men with and without FTCs). The restriction further ensures that workers with FTCs are not compared to workers with permanent contracts in firms that do not use FTCs. The number of observations in this estimation sample is 828,963 workers in 9,915 different firms.

As the chosen threshold values for the number of observations in a firm are quite arbitrary, I performed several robustness checks with respect to this sample restriction. The main findings are robust so that I present only the

\footnotetext{
${ }^{1}$ For detailed information about the data set see the homepage of the Research Data Centre of the German Federal Statistical Office (http://www.forschungsdatenzentrum.de/en/).

${ }^{2}$ Because the data set contains the entire population of firms and workers (1.8 million) from the education sector due to this procedure, the number of observations in the sample is enormously reduced when excluding the education sector.
}

additional results for a very conservative sample restriction ("large firms": at least 200 workers in the sample, of whom at least 50 have FTCs and at least 50 have permanent contracts) in this paper. As it is obvious that only few workers with FTCs have long tenure, two further robustness checks for restricted subsamples with respect to workers' tenure are applied. At first, I restrict the sample to workers with only one or two years of tenure, who amount for 78 percent of workers in the sample, and do not control for tenure in the regression analysis. Second, I restrict the sample to workers with a maximum of 6 years of tenure (96 percent of observations) and control for differences in tenure.

In order to analyze mean differences in wages between workers with FTCs and permanent contracts, I estimate loglinear earnings functions using ordinary least squares (OLS) regressions. An advantage of the German Structure of Earnings Survey is that it contains uncensored information about gross monthly earnings and monthly working hours so that hourly wages can be computed accurately. Five different specifications are estimated to get an understanding of how the inclusion of different sets of control variables affect the estimated wage differentials:

$$
\begin{aligned}
\log \text { WAGE }_{i}= & \alpha+\beta_{1} \text { FTC }_{i}+\varepsilon_{i} \\
\log \text { WAGE }_{i}= & \alpha+\beta_{1} \text { FTC }_{i}+\gamma_{1} A G E_{i}+\gamma_{2} A G E_{i}^{2} \\
& +\gamma_{3} \text { TENURE }_{i}+\gamma_{4} \text { TENURE }_{i}^{2} \\
& +\gamma_{5} \text { HOURS }_{i}+\gamma_{6} \text { HOURS }_{i}^{2} \\
& +\gamma_{7} \text { SCHOOLING }_{i}+\gamma_{8} \text { FEMALE }_{i} \\
& +\gamma_{9} \text { EAST }_{i}+\varepsilon_{i}
\end{aligned}
$$

$\log W A G E_{i}=\alpha+\beta_{1} F T C_{i}+\gamma_{1} A G E_{i}+\gamma_{2} A G E_{i}^{2}$

$$
+\gamma_{3} T_{E N U R E_{i}}+\gamma_{4} T_{E N U R E_{i}^{2}}
$$$$
+\gamma_{5} \mathrm{HOURS}_{i}+\gamma_{6} \mathrm{HOURS}_{i}^{2}
$$$$
+\gamma_{7} \text { SCHOOLING }_{i}+\gamma_{8} \text { FEMALE }_{i}
$$$$
+\gamma_{9} \text { EAST }_{i}+\delta_{1} \text { OCCUPATION }_{i}+\varepsilon_{i}
$$

$$
\begin{aligned}
\log \text { WAGE }_{i}= & \alpha+\beta_{1} \text { FTC }_{i}+\gamma_{1} A G E_{i}+\gamma_{2} A G E_{i}^{2} \\
& +\gamma_{3} \text { TENURE }_{i}+\gamma_{4} \text { TENURE }_{i}^{2} \\
& +\gamma_{5} \text { HOURS }_{i}+\gamma_{6} \text { HOURS }_{i}^{2} \\
& +\gamma_{7} \text { SCHOOLING }_{i}+\gamma_{8} \text { FEMALE }_{i} \\
& +\gamma_{9} \text { EAST }_{i}+\delta_{1} \text { OCCUPATION }_{i} \\
& +\lambda_{1} \text { FIRMSIZE }_{j}+\lambda_{2} \text { INDUSTRY }_{j}+\varepsilon_{i} \\
\log \text { WAGE }_{i}= & +\beta_{1} \text { FTC }_{i}+\gamma_{1} \text { AGE }_{i}+\gamma_{2} \text { AGE }_{i}^{2} \\
& +\gamma_{3} \text { TENURE }_{i}+\gamma_{4} \text { TENURE }_{i}^{2} \\
& +\gamma_{5} \text { HOURS }_{i}+\gamma_{6} \text { HOURS }_{i}^{2} \\
& +\gamma_{7} \text { SCHOOLING }_{i}+\gamma_{8} \text { FEMALE }_{i} \\
& +\delta_{1} \text { OCCUPATION }_{i}+v_{j}+\varepsilon_{i}
\end{aligned}
$$


In all specifications, the dependent variable is the log of the gross hourly wage $(\log W A G E), i$ is a worker index, $j$ is a firm index, $\alpha$ denotes the constant, $\varepsilon$ denotes the usual error term, $\beta, \gamma, \delta$, and $\lambda$ denote coefficients. The first regression is specified as in Eq. (1) and includes only a binary variable which takes the value one if a worker is employed with a FTC and zero if a worker is employed with a permanent contract. Thus, the estimated wage differential $\beta$ is the raw (unconditional) difference in mean $\log$ wages between workers in FTCs and permanent contracts. Because workers with FTCs and permanent contracts can differ in their (productivity relevant) characteristics, the second specification (2) includes age in years, tenure in years, monthly working hours, dummy variables for the highest schooling degree (none/unknown (reference), low/medium schooling without apprenticeship, low/medium schooling with apprenticeship, high schooling without apprenticeship, high schooling with apprenticeship, degree from university of applied science, degree from university), a dummy variable for working in East Germany, and a dummy variable for being female. Specification (3) takes further into account workers' occupations (56 occupations), because FTCs might be job related due to the nature of work in some occupations.

The next specification (4) includes also dummy variables for firm size categories ( $<100$ (reference), 100-499, 500 $999,1000-4999, \geq 5000$ ) and for the industry of the firm (28 industries), in which the worker is employed. This is a first step to deal with potential firm heterogeneity in a crude manner. In specification (5), firm heterogeneity is explicitly accounted for by the inclusion of firm fixed effects $v$. Therefore, specification (5) estimates the within-firm wage differential between workers with FTCs and with permanent contracts. Table 1 informs about descriptive statistics. Approximately $13 \%$ of workers in the sample have a FTC. Note that these shares of FTCs are larger than in the total population due to the imposed sample restrictions to analyze withinfirm wage differentials.

Obviously, we would expect that the estimated wage differential $\beta$ gets smaller if more control variables are included which are correlated positively with FTCs and negatively with wages (reduction of omitted variable bias). This is likely to be the case for variables that are correlated with worker and firm productivity. Whereas the firm fixed effects design prevents an omitted variable bias stemming from differences in firm productivity, the cross-section nature of the data does not allow worker fixed effects estimates. Moreover, no information about previous labor market experience such as unemployment or training is available in the data. The worker characteristics included in the regressions are, however, some of the most important determinants of worker productivity. Nevertheless, we should keep in mind that the main contribution of the subsequent regressions is the examination of how firm heterogeneity in general affects the estimated wage differentials.

The OLS estimates might be subject to heteroskedasticity so that I compute robust standard errors clustered at the firm-level. Another issue in log-linear regressions under group-specific heteroskedasticity is the correct interpretation of coefficients of dummy variables (for a detailed discussion see Winkelmann 2001). In the presence of heteroskedasticity, the usual transformation $(\exp (\beta)-1)$ is not the correct relative difference in percent between workers with FTCs and permanent contracts. The correct transformation needs to account for group-specific heteroskedasticity with an adjustment factor $Q:(\exp (\beta) Q-1)$. Following Winkelmann $(2001$, p. 425), I use the approximative $Q_{T}=\left(1+0.5 \hat{\sigma}_{F T C=1}\right) /\left(1+0.5 \hat{\sigma}_{F T C=0}\right)$ and $Q_{N}=$ $\exp \left(0.5\left(\hat{\sigma}_{F T C=1}-\hat{\sigma}_{F T C=0}\right)\right)$ under the assumption of normal distribution.

In the next step, we take a deeper look at the wage differentials across the wage distribution and estimate earnings functions with quantile regressions for different quantiles (5\%, $10 \%, 25 \%, 50 \%, 75 \%, 90 \%, 95 \%)$. Quantile regressions have also the advantage of informing us about the influence of potential outliers in the data. Thus, a comparison between estimated wage differentials between mean and median regressions is a worthwhile robustness check. Specification (4) with worker characteristics, occupations, firm size categories, and industries is estimated along with a sort of firm fixed effects quantile regression (specification (5)). The firm fixed effects quantile models are estimated in the following way. ${ }^{3}$ Using the results from the previous OLS models with firm fixed effects, I predict the firm-specific wage component $\left(v_{j}\right)$ and subtract it from workers' individual wages $\left(\log W A G E_{i}\right)$. These adjusted wages are then used as dependent variables in the quantile regressions. While not accounting for firm-specific features of the wage distribution, this procedures takes into account firm heterogeneity with respect to wage levels.

\section{Estimation results}

Table 2 presents the results for the mean wage differentials between workers with FTCs and permanent contracts. The unconditional mean wage differential in specification (1) is approximately $-0.406 \log$ points. As discussed in the previous section, the usual transformation $(\exp (\beta)-$ $1)((\exp (-0.406)-1)=-33.4 \%)$ is not the correct relative wage difference in percent between workers with FTCs and permanent contracts under group-specific heteroskedasticity. When accounting for group-specific heteroskedasticity in the transformation $(\exp (\beta) Q-1)$, the relative wage

\footnotetext{
${ }^{3}$ I thank Bernd Fitzenberger for suggesting this procedure for firm fixed effects quantile regressions.
} 


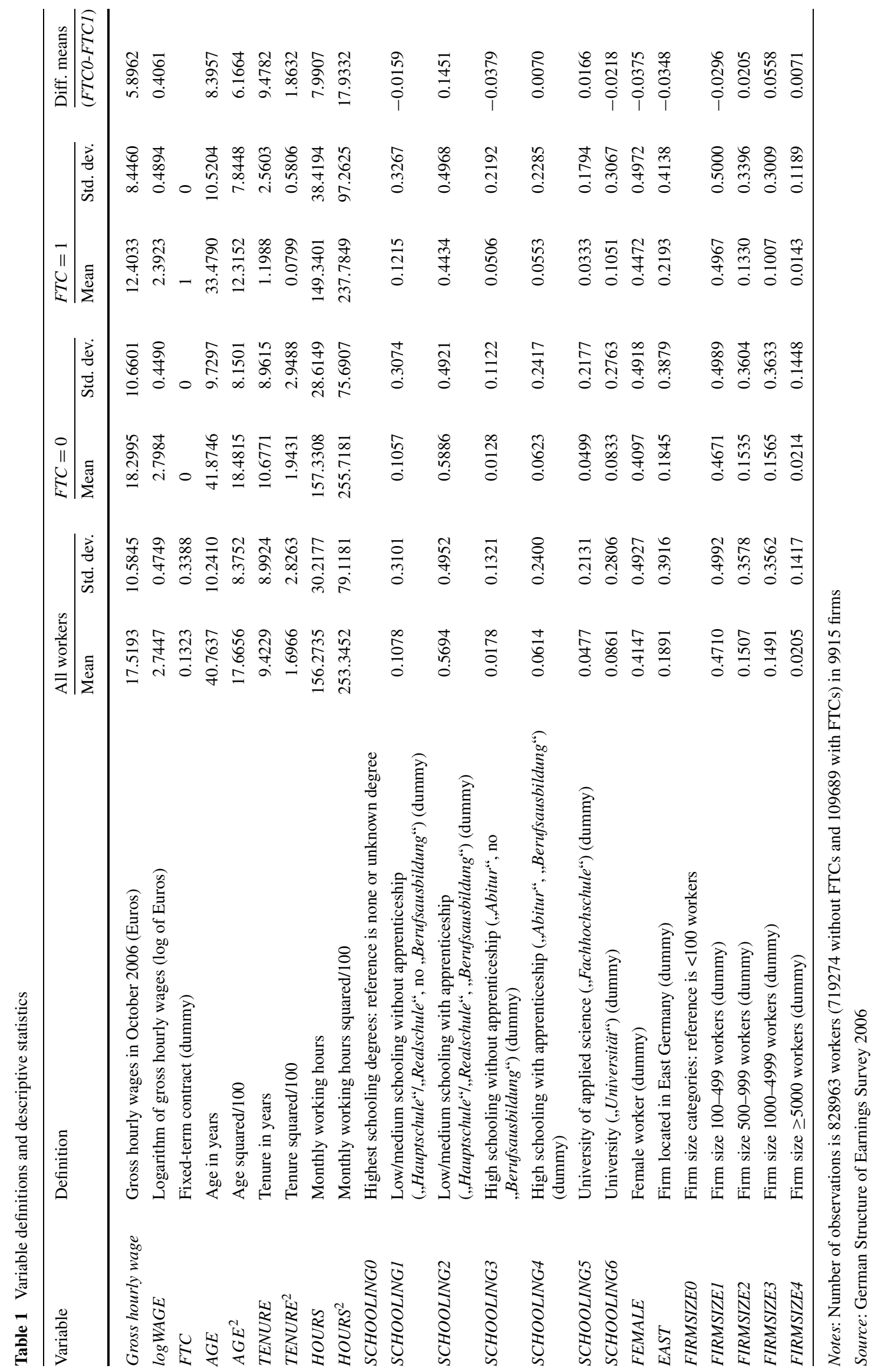


Table 2 Mean wage differentials between workers with FTCs and permanent contracts (OLS regressions)

\begin{tabular}{|c|c|c|c|c|c|}
\hline & (1) & $(2)$ & (3) & (4) & $(5)$ \\
\hline FTC & $\begin{array}{l}-0.4061^{* * *} \\
(0.00749)\end{array}$ & $\begin{array}{l}-0.1932^{* * *} \\
(0.00543)\end{array}$ & $\begin{array}{l}-0.1575^{* * *} \\
(0.00494)\end{array}$ & $\begin{array}{l}-0.1529^{* * *} \\
(0.00471)\end{array}$ & $\begin{array}{l}-0.1269^{* * *} \\
(0.00320)\end{array}$ \\
\hline$A G E$ & & $\begin{array}{l}0.0395^{* * *} \\
(0.00074)\end{array}$ & $\begin{array}{l}0.0383^{* * *} \\
(0.00067)\end{array}$ & $\begin{array}{l}0.0371^{* * *} \\
(0.00065)\end{array}$ & $\begin{array}{l}0.0339^{* * *} \\
(0.00052)\end{array}$ \\
\hline$A G E^{2}$ & & $\begin{array}{l}-0.0449^{* * *} \\
(0.00086)\end{array}$ & $\begin{array}{l}-0.0425^{* * *} \\
(0.00077)\end{array}$ & $\begin{array}{l}-0.0402^{* * *} \\
(0.00073)\end{array}$ & $\begin{array}{l}-0.0353^{* * *} \\
(0.00059)\end{array}$ \\
\hline TENURE & & $\begin{array}{l}0.0178^{* * *} \\
(0.00062)\end{array}$ & $\begin{array}{l}0.0166^{* * *} \\
(0.00052)\end{array}$ & $\begin{array}{l}0.0127^{* * *} \\
(0.00043)\end{array}$ & $\begin{array}{l}0.0111^{* * *} \\
(0.00025)\end{array}$ \\
\hline$T E N U R E^{2}$ & & $\begin{array}{l}-0.0216^{* * *} \\
(0.00153)\end{array}$ & $\begin{array}{l}-0.0244^{* * *} \\
(0.00129)\end{array}$ & $\begin{array}{l}-0.0192^{* * *} \\
(0.00111)\end{array}$ & $\begin{array}{l}-0.0172^{* * *} \\
(0.00063)\end{array}$ \\
\hline HOURS & & $\begin{array}{l}0.0055^{* * *} \\
(0.00039)\end{array}$ & $\begin{array}{l}0.0036^{* * *} \\
(0.00033)\end{array}$ & $\begin{array}{l}0.0028^{* * *} \\
(0.00031)\end{array}$ & $\begin{array}{l}-0.0010^{* *} \\
(0.00031)\end{array}$ \\
\hline$H O U R S^{2}$ & & $\begin{array}{l}-0.0022^{* * *} \\
(0.00015)\end{array}$ & $\begin{array}{l}-0.0016^{* * *} \\
(0.00012)\end{array}$ & $\begin{array}{l}-0.0013^{* * *} \\
(0.00012)\end{array}$ & $\begin{array}{l}0.0005^{* * *} \\
(0.00012)\end{array}$ \\
\hline SCHOOLING1 & & $\begin{array}{l}-0.1286^{* * *} \\
(0.00905)\end{array}$ & $\begin{array}{l}-0.0458^{* * *} \\
(0.00671)\end{array}$ & $\begin{array}{l}-0.0570^{* * *} \\
(0.00602)\end{array}$ & $\begin{array}{l}-0.0578^{* * *} \\
(0.00422)\end{array}$ \\
\hline SCHOOLING2 & & $\begin{array}{l}0.0859^{* * *} \\
(0.00825)\end{array}$ & $\begin{array}{l}0.0467^{* * *} \\
(0.00617)\end{array}$ & $\begin{array}{l}0.0290^{* * *} \\
(0.00564)\end{array}$ & $\begin{array}{l}0.0350^{* * *} \\
(0.00392)\end{array}$ \\
\hline SCHOOLING3 & & $\begin{array}{l}0.0816^{* * *} \\
(0.01408)\end{array}$ & $\begin{array}{l}-0.0157 \\
(0.01275)\end{array}$ & $\begin{array}{l}-0.0567^{* * *} \\
(0.01236)\end{array}$ & $\begin{array}{l}-0.0945^{* * *} \\
(0.00987)\end{array}$ \\
\hline SCHOOLING4 & & $\begin{array}{l}0.3289 * * * \\
(0.00889)\end{array}$ & $\begin{array}{l}0.1675^{* * *} \\
(0.00702)\end{array}$ & $\begin{array}{c}0.1337^{* * *} \\
(0.00678)\end{array}$ & $\begin{array}{l}0.1068^{* * *} \\
(0.00479)\end{array}$ \\
\hline SCHOOLING5 & & $\begin{array}{l}0.4902^{* * *} \\
(0.00914)\end{array}$ & $\begin{array}{l}0.2732^{* * *} \\
(0.00747)\end{array}$ & $\begin{array}{l}0.2299^{* * *} \\
(0.00698)\end{array}$ & $\begin{array}{l}0.1958^{* * *} \\
(0.00488)\end{array}$ \\
\hline SCHOOLING6 & & $\begin{array}{l}0.6478^{* * *} \\
(0.00973)\end{array}$ & $\begin{array}{l}0.4116^{* * *} \\
(0.00885)\end{array}$ & $\begin{array}{l}0.3656^{* * *} \\
(0.00844)\end{array}$ & $\begin{array}{l}0.3173^{* * *} \\
(0.00710)\end{array}$ \\
\hline FEMALE & & $\begin{array}{l}-0.1907^{* * *} \\
(0.00354)\end{array}$ & $\begin{array}{l}-0.2100^{* * *} \\
(0.00282)\end{array}$ & $\begin{array}{l}-0.2021^{* * *} \\
(0.00272)\end{array}$ & $\begin{array}{l}-0.1651^{* * *} \\
(0.00186)\end{array}$ \\
\hline$E A S T$ & & $\begin{array}{l}-0.2961^{* * *} \\
(0.00787)\end{array}$ & $\begin{array}{l}-0.2653^{* * *} \\
(0.00676)\end{array}$ & $\begin{array}{l}-0.2588^{* * *} \\
(0.00602)\end{array}$ & \\
\hline FIRMSIZE1 & & & & $\begin{array}{l}0.0527^{* * *} \\
(0.00425)\end{array}$ & \\
\hline FIRMSIZE2 & & & & $\begin{array}{l}0.0985^{* * *} \\
(0.00772)\end{array}$ & \\
\hline FIRMSIZE3 & & & & $\begin{array}{c}0.1599^{* * *} \\
(0.00879)\end{array}$ & \\
\hline FIRMSIZE4 & & & & $\begin{array}{l}0.1898^{* * *} \\
(0.02036)\end{array}$ & \\
\hline OCCUPATION (56) & No & No & Yes & Yes & Yes \\
\hline $\operatorname{INDUSTRY}(28)$ & No & No & No & Yes & No \\
\hline FIRM FIXED EFFECT (9915) & No & No & No & No & Yes \\
\hline CONSTANT & $\begin{array}{l}2.7984^{* * *} \\
(0.00474)\end{array}$ & $\begin{array}{l}1.5180^{* * *} \\
(0.02891)\end{array}$ & $\begin{array}{l}1.5233^{* * *} \\
(0.03561)\end{array}$ & $\begin{array}{l}1.6950^{* * *} \\
(0.04687)\end{array}$ & $\begin{array}{l}1.8636^{* * *} \\
(0.02458)\end{array}$ \\
\hline$R^{2}$ & 0.0840 & 0.4520 & 0.5499 & 0.5791 & 0.7095 \\
\hline Number of workers & 828963 & 828963 & 828963 & 828963 & 828963 \\
\hline
\end{tabular}

Notes: Ordinary least squares regressions for log hourly wages. Robust standard errors clustered at the firm-level in parentheses. Coefficients are significant at ${ }^{*} p<0.05,{ }^{* *} p<0.01$, and ${ }^{* * *} p<0.001$

Source: German Structure of Earnings Survey 2006 
difference is about one percentage point smaller $(-32.1 \%$ for $Q_{N}$ and $-32.2 \%$ for $\left.Q_{T}\right)$. Because the transformation bias is even more pronounced in the subsequent estimates (about two to three percentage points) and differences between the $Q_{N}$ and $Q_{T}$ transformations are small, only the correct transformation under heteroskedasticity for the normal distribution assumption $\left(Q_{N}\right)$ will be discussed. Table 7 in the Appendix presents all transformation results.

When accounting for differences in worker characteristics in specification (2) the wage differential decreases by about the half to $-0.193 \log$ points $(-15.3 \%)$. The wage differential further decreases to $-0.158 \log$ points $(-11.7 \%)$ in specification (3), which includes workers' occupations. Specification (4) contains also firm size categories and the firm's industry, in which a worker is employed. The impact of these firm characteristics on the estimated wage differential is small, because it decreases only by about 0.005 to $-0.153 \log$ points $(-11.3 \%)$. The last specification (5) accounts for firm heterogeneity through the inclusion of firm fixed effects and estimates the within-firm wage differential between workers in FTCs and in permanent contracts. The within-firm wage differential is -0.127 $\log$ points $(-9.4 \%)$, which is about $0.03 \log$ points smaller than in specification (3) that does not control for firm characteristics.

The findings show that workers with FTCs earn on average significant lower wages than workers with permanent contracts, even when accounting for a variety of worker characteristics and occupations and when taking a withinfirm perspective. Moreover, the comparison of the wage differentials across the five specifications indicates that worker characteristics have the largest impact on the estimated wage differentials in terms of an omitted variable bias. Whereas workers' occupations and unobserved firm heterogeneity also have sizeable impact on the estimated wage differential, the impact of industries seems not to be very important.

The main focus of the previous regressions was to estimate the mean wage differential between workers with FTCs and permanent contracts and to evaluate the impact of different sets of control variables on the size of the estimated wage differential. It seems, however, reasonable to assume heterogeneity of the wage differential across the wage distribution, which is analyzed using quantile regressions. The results for specification (4) are presented in Table 3. At first, let us take a look at the median (50\%-quantile) regression. The estimated wage differential is $-0.112 \log$ points and substantially smaller than in the mean regression (see specification (4) in Table 2), which indeed points to heterogeneity across the wage distribution. When looking separately at the quantiles, we can see that the wage differentials are larger at the lower tail of the wage distribution and quite homogeneous in the middle and upper part of the wage distribution $(-0.275 \log$ points at the $5 \%$-quantile, -0.190 at $10 \%$, -0.132 at $25 \%,-0.112$ at $50 \%,-0.108$ at $75 \%,-0.107$ at $90 \%$, and -0.109 at $95 \%$ ). The coefficients for FTC in the fixed effects quantile regression models (specification (5)) in Table 4 are about 0.02 to $0.04 \log$ points smaller $(-0.245$ $\log$ points at the $5 \%$-quantile, -0.153 at $10 \%,-0.105$ at $25 \%,-0.088$ at $50 \%,-0.086$ at $75 \%,-0.089$ at $90 \%$, and -0.094 at $95 \%$ ) than without subtracting the firm-specific wage levels in Table 3 (specification (4)). The main results are however supported. The findings fit the theoretical consideration that, if workers at the lower tail of the wage distribution have bad labor market opportunities, wages of such workers with FTCs might be especially low due to excess labor supply (e.g., low bargaining potential, extended probation period).

As a robustness check, I have estimated all OLS regressions and the firm fixed effects quantile regressions for three subsamples (see Sect. 2 for further details): workers in large firms, workers with a maximum of two years of tenure (without control for tenure), and workers with a maximum of six years of tenure (with control for tenure). The results for the mean wage differentials are summarized in Table 5 and the results for the quantile regressions are summarized in Table 6 . The estimated wage disadvantage is smaller in large firms than in the total sample, but the findings confirm that worker and firm characteristics affect the estimated mean wage differential. In these larger firms, wage differentials are largest at the lower tail of the wage distribution, while quite homogeneous in the middle part and slightly increasing again in the upper part of the wage distribution. The sample restrictions with respect to tenure reveal more noteworthy differences. First of all, the wage disadvantage of workers with FTCs is larger in the sample of workers with a maximum of two years of tenure. In this sample, firm characteristics (firm size, industry, firm fixed effects) do not seem to affect the size of the estimated wage differential. In the less restrictive sample for workers with a maximum tenure of six years, the inclusion of firm fixed effects reduces however the size of the estimated wage differential, as was the case for the other samples. The quantile regressions for the restricted tenure samples further indicate that the wage disadvantage of workers with FTCs is significantly larger at the lower and at the upper tail than in the middle of the wage distribution. Overall, the robustness checks support the finding of a significant wage disadvantage of workers with FTCs across the entire wage distribution.

My results are in line with previous findings and the size of the estimated wage differentials between workers with FTCs and permanent contracts in my analysis concurs with previous studies for Germany. For example, Hagen (2002) and Mertens and McGinnity (2005), who use GSOEP data, 
Table 3 Wage differentials between workers with FTCs and permanent contracts across the wage distribution without firm fixed effects (quantile regressions, specification (4))

\begin{tabular}{|c|c|c|c|c|c|c|c|}
\hline & $5 \%$ & $10 \%$ & $25 \%$ & $50 \%$ & $75 \%$ & $90 \%$ & $95 \%$ \\
\hline FTC & $\begin{array}{l}-0.2752^{* * *} \\
(0.00210)\end{array}$ & $\begin{array}{l}-0.1898^{* * *} \\
(0.00159)\end{array}$ & $\begin{array}{l}-0.1315^{* * *} \\
(0.00126)\end{array}$ & $\begin{array}{l}-0.1122^{* * *} \\
(0.00118)\end{array}$ & $\begin{array}{l}-0.1082^{* * *} \\
(0.00142)\end{array}$ & $\begin{array}{l}-0.1066^{* * *} \\
(0.00206)\end{array}$ & $\begin{array}{l}-0.1091^{* * *} \\
(0.00288)\end{array}$ \\
\hline$A G E$ & $\begin{array}{l}0.0404^{* * *} \\
(0.00049)\end{array}$ & $\begin{array}{l}0.0339^{* * *} \\
(0.00036)\end{array}$ & $\begin{array}{l}0.0313^{* * *} \\
(0.00027)\end{array}$ & $\begin{array}{l}0.0314^{* * *} \\
(0.00026)\end{array}$ & $\begin{array}{l}0.0322^{* * *} \\
(0.00031)\end{array}$ & $\begin{array}{l}0.0322^{* * *} \\
(0.00047)\end{array}$ & $\begin{array}{l}0.0325^{* * *} \\
(0.00066)\end{array}$ \\
\hline$A G E^{2}$ & $\begin{array}{l}-0.0467^{* * *} \\
(0.00059)\end{array}$ & $\begin{array}{l}-0.0390^{* * *} \\
(0.00043)\end{array}$ & $\begin{array}{l}-0.0354^{* * *} \\
(0.00033)\end{array}$ & $\begin{array}{l}-0.0346^{* * *} \\
(0.00031)\end{array}$ & $\begin{array}{l}-0.0343^{* * *} \\
(0.00038)\end{array}$ & $\begin{array}{l}-0.0327^{* * *} \\
(0.00057)\end{array}$ & $\begin{array}{l}-0.0317^{* * *} \\
(0.00080)\end{array}$ \\
\hline TENURE & $\begin{array}{l}0.0176^{* * *} \\
(0.00024)\end{array}$ & $\begin{array}{l}0.0171^{* * *} \\
(0.00018)\end{array}$ & $\begin{array}{l}0.0158^{* * *} \\
(0.00014)\end{array}$ & $\begin{array}{l}0.0134^{* * *} \\
(0.00013)\end{array}$ & $\begin{array}{l}0.0111^{* * *} \\
(0.00016)\end{array}$ & $\begin{array}{l}0.0092^{* * *} \\
(0.00024)\end{array}$ & $\begin{array}{l}0.0081^{* * *} \\
(0.00033)\end{array}$ \\
\hline TENURE ${ }^{2}$ & $\begin{array}{l}-0.0280^{* * *} \\
(0.00069)\end{array}$ & $\begin{array}{l}-0.0275^{* * *} \\
(0.00051)\end{array}$ & $\begin{array}{l}-0.0253^{* * *} \\
(0.00040)\end{array}$ & $\begin{array}{l}-0.0205^{* * *} \\
(0.00038)\end{array}$ & $\begin{array}{l}-0.0165^{* * *} \\
(0.00047)\end{array}$ & $\begin{array}{l}-0.0135^{* * *} \\
(0.00070)\end{array}$ & $\begin{array}{l}-0.0122^{* * *} \\
(0.00097)\end{array}$ \\
\hline HOURS & $\begin{array}{l}0.0073^{* * *} \\
(0.00010)\end{array}$ & $\begin{array}{l}0.0064^{* * *} \\
(0.00008)\end{array}$ & $\begin{array}{l}0.0056^{* * *} \\
(0.00006)\end{array}$ & $\begin{array}{l}0.0045^{* * *} \\
(0.00006)\end{array}$ & $\begin{array}{l}0.0032^{* * *} \\
(0.00008)\end{array}$ & $\begin{array}{l}0.0008^{* * *} \\
(0.00012)\end{array}$ & $\begin{array}{l}-0.0029^{* * *} \\
(0.00017)\end{array}$ \\
\hline$H O U R S^{2}$ & $\begin{array}{l}-0.0029^{* * *} \\
(0.00004)\end{array}$ & $\begin{array}{l}-0.0026^{* * *} \\
(0.00003)\end{array}$ & $\begin{array}{l}-0.0023^{* * *} \\
(0.00002)\end{array}$ & $\begin{array}{l}-0.0018^{* * *} \\
(0.00002)\end{array}$ & $\begin{array}{l}-0.0014^{* * *} \\
(0.00003)\end{array}$ & $\begin{array}{l}-0.0006^{* * *} \\
(0.00004)\end{array}$ & $\begin{array}{l}0.0007^{* * *} \\
(0.00006)\end{array}$ \\
\hline SCHOOLING1 & $\begin{array}{l}-0.0150^{* * *} \\
(0.00292)\end{array}$ & $\begin{array}{l}-0.0137^{* * *} \\
(0.00216)\end{array}$ & $\begin{array}{l}-0.0221^{* * *} \\
(0.00165)\end{array}$ & $\begin{array}{l}-0.0304^{* * *} \\
(0.00153)\end{array}$ & $\begin{array}{l}-0.0550^{* * *} \\
(0.00181)\end{array}$ & $\begin{array}{l}-0.0961^{* * *} \\
(0.00261)\end{array}$ & $\begin{array}{l}-0.1228^{* * *} \\
(0.00361)\end{array}$ \\
\hline SCHOOLING2 & $\begin{array}{l}0.0915^{* * *} \\
(0.00224)\end{array}$ & $\begin{array}{l}0.0754^{* * *} \\
(0.00166)\end{array}$ & $\begin{array}{l}0.0563^{* * *} \\
(0.00128)\end{array}$ & $\begin{array}{l}0.0431^{* * *} \\
(0.00119)\end{array}$ & $\begin{array}{l}0.0162^{* * *} \\
(0.00143)\end{array}$ & $\begin{array}{l}-0.0208^{* * *} \\
(0.00209)\end{array}$ & $\begin{array}{l}-0.0431^{\text {*** }} \\
(0.00292)\end{array}$ \\
\hline SCHOOLING3 & $\begin{array}{l}-0.3598^{* * *} \\
(0.00523)\end{array}$ & $\begin{array}{l}-0.2606^{* * *} \\
(0.00385)\end{array}$ & $\begin{array}{l}-0.0716^{* * *} \\
(0.00298)\end{array}$ & $\begin{array}{l}0.0143^{* * *} \\
(0.00281)\end{array}$ & $\begin{array}{l}0.0534^{* * *} \\
(0.00340)\end{array}$ & $\begin{array}{l}0.0507^{* * *} \\
(0.00498)\end{array}$ & $\begin{array}{l}0.0308^{* * *} \\
(0.00697)\end{array}$ \\
\hline SCHOOLING4 & $\begin{array}{l}0.1714^{* * *} \\
(0.00337)\end{array}$ & $\begin{array}{l}0.1530^{* * *} \\
(0.00249)\end{array}$ & $\begin{array}{l}0.1383^{* * *} \\
(0.00192)\end{array}$ & $\begin{array}{l}0.1346^{* * *} \\
(0.00180)\end{array}$ & $\begin{array}{l}0.1236^{* * *} \\
(0.00219)\end{array}$ & $\begin{array}{l}0.1059^{* * *} \\
(0.00323)\end{array}$ & $\begin{array}{l}0.0945^{* * *} \\
(0.00454)\end{array}$ \\
\hline SCHOOLING5 & $\begin{array}{c}0.2930^{* * *} \\
(0.00388)\end{array}$ & $\begin{array}{l}0.2786^{* * *} \\
(0.00284)\end{array}$ & $\begin{array}{l}0.2567^{* * *} \\
(0.00217)\end{array}$ & $\begin{array}{l}0.2380^{* * *} \\
(0.00203)\end{array}$ & $\begin{array}{l}0.2132^{* * *} \\
(0.00250)\end{array}$ & $\begin{array}{l}0.1787^{* * *} \\
(0.00373)\end{array}$ & $\begin{array}{l}0.1548^{* * *} \\
(0.00528)\end{array}$ \\
\hline SCHOOLING6 & $\begin{array}{l}0.3868^{* * *} \\
(0.00332)\end{array}$ & $\begin{array}{l}0.3815^{* * *} \\
(0.00244)\end{array}$ & $\begin{array}{l}0.3687^{* * *} \\
(0.00186)\end{array}$ & $\begin{array}{l}0.3585^{* * *} \\
(0.00175)\end{array}$ & $\begin{array}{l}0.3627^{* * *} \\
(0.00220)\end{array}$ & $\begin{array}{l}0.3888^{* * *} \\
(0.00335)\end{array}$ & $\begin{array}{l}0.4028^{* * *} \\
(0.00475)\end{array}$ \\
\hline FEMALE & $\begin{array}{l}-0.1762^{* * *} \\
(0.00172)\end{array}$ & $\begin{array}{l}-0.1728^{* * *} \\
(0.00125)\end{array}$ & $\begin{array}{l}-0.1703^{* * *} \\
(0.00093)\end{array}$ & $\begin{array}{l}-0.1805^{* * *} \\
(0.00084)\end{array}$ & $\begin{array}{l}-0.2076^{* * *} \\
(0.00101)\end{array}$ & $\begin{array}{l}-0.2429^{* * *} \\
(0.00152)\end{array}$ & $\begin{array}{l}-0.2575^{\text {*** }} \\
(0.00217)\end{array}$ \\
\hline$E A S T$ & $\begin{array}{l}-0.2727^{* * *} \\
(0.00177)\end{array}$ & $\begin{array}{l}-0.2718^{* * *} \\
(0.00131)\end{array}$ & $\begin{array}{l}-0.2630^{* * *} \\
(0.00101)\end{array}$ & $\begin{array}{l}-0.2494^{* * *} \\
(0.00095)\end{array}$ & $\begin{array}{l}-0.2453^{* * *} \\
(0.00114)\end{array}$ & $\begin{array}{l}-0.2520^{* * *} \\
(0.00166)\end{array}$ & $\begin{array}{l}-0.2584^{* * *} \\
(0.00232)\end{array}$ \\
\hline FIRMSIZE1 & $\begin{array}{l}0.0682^{* * *} \\
(0.00170)\end{array}$ & $\begin{array}{l}0.0647^{* * *} \\
(0.00126)\end{array}$ & $\begin{array}{l}0.0581^{* * *} \\
(0.00097)\end{array}$ & $\begin{array}{l}0.0503^{* * *} \\
(0.00091)\end{array}$ & $\begin{array}{l}0.0454^{* * *} \\
(0.00109)\end{array}$ & $\begin{array}{l}0.0433^{* * *} \\
(0.00158)\end{array}$ & $\begin{array}{l}0.0415^{* * *} \\
(0.00220)\end{array}$ \\
\hline FIRMSIZE2 & $\begin{array}{l}0.1081^{* * *} \\
(0.00220)\end{array}$ & $\begin{array}{l}0.1075^{* * *} \\
(0.00163)\end{array}$ & $\begin{array}{l}0.1033^{* * *} \\
(0.00127)\end{array}$ & $\begin{array}{l}0.1009^{* * *} \\
(0.00119)\end{array}$ & $\begin{array}{l}0.0967^{* * *} \\
(0.00143)\end{array}$ & $\begin{array}{l}0.0888^{* * *} \\
(0.00209)\end{array}$ & $\begin{array}{l}0.0784^{* * *} \\
(0.00292)\end{array}$ \\
\hline FIRMSIZE3 & $\begin{array}{l}0.1976^{* * *} \\
(0.00230)\end{array}$ & $\begin{array}{l}0.1870^{* * *} \\
(0.00170)\end{array}$ & $\begin{array}{l}0.1721^{* * *} \\
(0.00131)\end{array}$ & $\begin{array}{l}0.1576^{* * *} \\
(0.00122)\end{array}$ & $\begin{array}{l}0.1453^{* * *} \\
(0.00148)\end{array}$ & $\begin{array}{l}0.1300^{* * *} \\
(0.00215)\end{array}$ & $\begin{array}{l}0.1182^{* * *} \\
(0.00300)\end{array}$ \\
\hline FIRMSIZE4 & $\begin{array}{c}0.2723^{* * *} \\
(0.00518)\end{array}$ & $\begin{array}{l}0.2461^{* * *} \\
(0.00380)\end{array}$ & $\begin{array}{l}0.2046^{* * *} \\
(0.00288)\end{array}$ & $\begin{array}{l}0.1730^{* * *} \\
(0.00265)\end{array}$ & $\begin{array}{l}0.1517^{* * *} \\
(0.00315)\end{array}$ & $\begin{array}{c}0.1358^{* * *} \\
(0.00457)\end{array}$ & $\begin{array}{l}0.1353^{* * *} \\
(0.00637)\end{array}$ \\
\hline OCCUPATION (56) & Yes & Yes & Yes & Yes & Yes & Yes & Yes \\
\hline $\operatorname{INDUSTRY}(28)$ & Yes & Yes & Yes & Yes & Yes & Yes & Yes \\
\hline FIRM FIXED EFFECT (9915) & No & No & No & No & No & No & No \\
\hline CONSTANT & $\begin{array}{l}0.8428^{* * *} \\
(0.01849)\end{array}$ & $\begin{array}{l}1.1324^{* * *} \\
(0.01367)\end{array}$ & $\begin{array}{l}1.4296^{* * *} \\
(0.01060)\end{array}$ & $\begin{array}{l}1.6899^{* * *} \\
(0.00997)\end{array}$ & $\begin{array}{l}1.9557^{* * *} \\
(0.01212)\end{array}$ & $\begin{array}{l}2.3406^{* * *} \\
(0.01794)\end{array}$ & $\begin{array}{l}2.7015^{* * *} \\
(0.02535)\end{array}$ \\
\hline Number of workers & 828963 & 828963 & 828963 & 828963 & 828963 & 828963 & 828963 \\
\hline Wages at quantiles & 2.0161 & 2.1632 & 2.4410 & 2.7309 & 3.0314 & 3.3525 & 3.5416 \\
\hline
\end{tabular}

Notes: Quantile regressions for log hourly wages, specification (4). Standard errors in parentheses. Coefficients are significant at $* p<0.05$, ${ }^{* *} p<0.01$, and ${ }^{* * *} p<0.001$

Source: German Structure of Earnings Survey 2006 
Table 4 Wage differentials between workers with FTCs and permanent contracts across the wage distribution with firm fixed effects for wage levels (quantile regressions, specification (5))

\begin{tabular}{|c|c|c|c|c|c|c|c|}
\hline & $5 \%$ & $10 \%$ & $25 \%$ & $50 \%$ & $75 \%$ & $90 \%$ & $95 \%$ \\
\hline \multirow[t]{2}{*}{$F T C$} & $-0.2452^{* * *}$ & $-0.1531^{* * *}$ & $-0.1051^{* * *}$ & $-0.0879^{* * *}$ & $-0.0857^{* * *}$ & $-0.0894^{* * *}$ & $-0.0944^{* * *}$ \\
\hline & $(0.00166)$ & $(0.00123)$ & $(0.00090)$ & $(0.00085)$ & $(0.00116)$ & $(0.00182)$ & $(0.00263)$ \\
\hline \multirow[t]{2}{*}{$A G E$} & $0.0415^{* * *}$ & $0.0346^{* * *}$ & $0.0290^{* * *}$ & $0.0267^{* * *}$ & $0.0262^{* * *}$ & $0.0267^{* * *}$ & $0.0273^{* * *}$ \\
\hline & $(0.00039)$ & $(0.00028)$ & $(0.00020)$ & $(0.00018)$ & $(0.00026)$ & $(0.00042)$ & $(0.00061)$ \\
\hline \multirow[t]{2}{*}{$A G E^{2}$} & $-0.0463^{* * *}$ & $-0.0383^{* * *}$ & $-0.0316^{* * *}$ & $-0.0285^{* * *}$ & $-0.0271^{* * *}$ & $-0.0260^{* * *}$ & $-0.0253^{* * *}$ \\
\hline & $(0.00047)$ & $(0.00033)$ & $(0.00024)$ & $(0.00022)$ & $(0.00031)$ & $(0.00051)$ & $(0.00074)$ \\
\hline \multirow[t]{2}{*}{ TENURE } & $0.0148^{* * *}$ & $0.0144^{* * *}$ & $0.0134^{* * *}$ & $0.0121^{* * *}$ & $0.0099^{* * *}$ & $0.0080^{* * *}$ & $0.0069^{* * *}$ \\
\hline & $(0.00019)$ & $(0.00014)$ & $(0.00010)$ & (0.00009) & $(0.00013)$ & $(0.00020)$ & $(0.00030)$ \\
\hline \multirow[t]{2}{*}{ TENURE ${ }^{2}$} & $-0.0255^{* * *}$ & $-0.0248^{* * *}$ & $-0.0223^{* * *}$ & $-0.0193^{* * *}$ & $-0.0137^{* * *}$ & $-0.0102^{* * *}$ & $-0.0089^{* * *}$ \\
\hline & $(0.00053)$ & $(0.00039)$ & $(0.00028)$ & $(0.00027)$ & $(0.00038)$ & $(0.00061)$ & $(0.00089)$ \\
\hline \multirow[t]{2}{*}{ HOURS } & $0.0026^{* * *}$ & $0.0017^{* * *}$ & $0.0010^{* * *}$ & $0.0002^{* * *}$ & $-0.0008^{* * *}$ & $-0.0035^{* * *}$ & $-0.0076^{* * *}$ \\
\hline & $(0.00010)$ & $(0.00007)$ & $(0.00005)$ & $(0.00005)$ & $(0.00006)$ & $(0.00010)$ & $(0.00015)$ \\
\hline \multirow[t]{2}{*}{$H O U R S^{2}$} & $-0.0008^{* * *}$ & $-0.0005^{* * *}$ & $-0.0002^{* * *}$ & $0.0001^{* *}$ & $0.0004^{* * *}$ & $0.0014^{* * *}$ & $0.0028^{* * *}$ \\
\hline & $(0.00004)$ & $(0.00003)$ & $(0.00002)$ & $(0.00002)$ & $(0.00002)$ & $(0.00004)$ & $(0.00005)$ \\
\hline \multirow[t]{2}{*}{ SCHOOLING1 } & $-0.0166^{* * *}$ & $-0.0239^{* * *}$ & $-0.0306^{* * *}$ & $-0.0390^{* * *}$ & $-0.0600^{* * *}$ & $-0.0928^{* * *}$ & $-0.1165^{* * *}$ \\
\hline & $(0.00228)$ & $(0.00165)$ & $(0.00117)$ & (0.00109) & $(0.00148)$ & $(0.00231)$ & $(0.00332)$ \\
\hline \multirow[t]{2}{*}{ SCHOOLING2 } & $0.0857^{* * *}$ & $0.0702^{* * *}$ & $0.0537^{* * *}$ & $0.0407^{* * *}$ & $0.0200^{* * *}$ & $-0.0093^{* * *}$ & $-0.0275^{* * *}$ \\
\hline & $(0.00175)$ & $(0.00127)$ & $(0.00091)$ & $(0.00085)$ & $(0.00116)$ & $(0.00183)$ & $(0.00264)$ \\
\hline \multirow[t]{2}{*}{ SCHOOLING3 } & $-0.4364^{* * *}$ & $-0.3309^{* * *}$ & $-0.1068^{* * *}$ & $-0.0261^{* * *}$ & $0.0109^{* * *}$ & $0.0118^{* *}$ & $0.0150^{*}$ \\
\hline & $(0.00415)$ & $(0.00299)$ & $(0.00212)$ & $(0.00201)$ & $(0.00277)$ & $(0.00438)$ & $(0.00634)$ \\
\hline \multirow[t]{2}{*}{ SCHOOLING4 } & $0.1376^{* * *}$ & $0.1172^{* * *}$ & $0.1027^{* * *}$ & $0.1015^{* * *}$ & $0.1010^{* * *}$ & $0.0973^{* * *}$ & $0.0950^{* * *}$ \\
\hline & $(0.00269)$ & $(0.00194)$ & $(0.00137)$ & $(0.00128)$ & $(0.00177)$ & $(0.00282)$ & $(0.00411)$ \\
\hline \multirow[t]{2}{*}{ SCHOOLING5 } & $0.2326^{* * *}$ & $0.2161^{* * *}$ & $0.2045^{* * *}$ & $0.1988^{* * *}$ & $0.1868^{* * *}$ & $0.1711^{* * *}$ & $0.1597^{* * *}$ \\
\hline & $(0.00309)$ & $(0.00222)$ & $(0.00155)$ & $(0.00145)$ & $(0.00202)$ & $(0.00325)$ & $(0.00475)$ \\
\hline \multirow[t]{2}{*}{ SCHOOLING6 } & $0.3055^{* * *}$ & $0.2949^{* * *}$ & $0.2944^{* * *}$ & $0.3028^{* * *}$ & $0.3312^{* * *}$ & $0.3715^{* * *}$ & $0.3826^{* * *}$ \\
\hline & $(0.00265)$ & $(0.00191)$ & $(0.00133)$ & $(0.00125)$ & $(0.00176)$ & $(0.00288)$ & $(0.00424)$ \\
\hline \multirow[t]{2}{*}{ FEMALE } & $-0.1258^{* * *}$ & $-0.1250^{* * *}$ & $-0.1294^{* * *}$ & $-0.1481^{* * *}$ & $-0.1782^{* * *}$ & $-0.2115^{* * *}$ & $-0.2359^{* * *}$ \\
\hline & $(0.00135)$ & $(0.00096)$ & $(0.00066)$ & $(0.00060)$ & $(0.00082)$ & $(0.00134)$ & $(0.00198)$ \\
\hline OCCUPATION (56) & Yes & Yes & Yes & Yes & Yes & Yes & Yes \\
\hline INDUSTRY (28) & No & No & No & No & No & No & No \\
\hline FIRM FIXED EFFECT (9915) & Yes & Yes & Yes & Yes & Yes & Yes & Yes \\
\hline \multirow[t]{2}{*}{ CONSTANT } & $1.1458^{* * *}$ & $1.4253^{* * *}$ & $1.7020^{* * *}$ & $1.9136^{* * *}$ & $2.1367^{* * *}$ & $2.4727^{* * *}$ & $2.8455^{* * *}$ \\
\hline & $(0.01303)$ & $(0.00938)$ & $(0.00663)$ & $(0.00620)$ & $(0.00853)$ & $(0.01368)$ & $(0.02007)$ \\
\hline Number of workers & 828963 & 828963 & 828963 & 828963 & 828963 & 828963 & 828963 \\
\hline Wages at quantiles & 2.2520 & 2.3546 & 2.5233 & 2.7140 & 2.9379 & 3.1905 & 3.3574 \\
\hline
\end{tabular}

Notes: Quantile regressions for log hourly wages, specification (5). Standard errors in parentheses. Coefficients are significant at $* p<0.05$, ** $p<0.01$, and ${ }^{* * *} p<0.001$

Source: German Structure of Earnings Survey 2006

also report significant wage disadvantages of workers with FTCs. Their estimated wage differentials range from about minus five percent to more than twenty percent and are larger at the lower tail of the wage distribution.

\section{Conclusion}

I have used administrative linked employer-employee data from the German Federal Statistical Office (German Struc- 
Table 5 Mean wage differentials between workers with FTCs and permanent contracts (OLS regressions) for subsamples

\begin{tabular}{|c|c|c|c|c|c|}
\hline & (1) & (2) & (3) & (4) & $(5)$ \\
\hline \multicolumn{6}{|l|}{ Subsample "large firms" } \\
\hline FTC & $\begin{array}{l}-0.2239^{* * *} \\
(0.04025)\end{array}$ & $\begin{array}{l}-0.1421^{* * *} \\
(0.03085)\end{array}$ & $\begin{array}{l}-0.1262^{* * *} \\
(0.02548)\end{array}$ & $\begin{array}{l}-0.1148^{* * *} \\
(0.02300)\end{array}$ & $\begin{array}{l}-0.0942^{* * *} \\
(0.02024)\end{array}$ \\
\hline Worker characteristics & No & Yes & Yes & Yes & Yes \\
\hline Firm characteristics & No & No & No & Yes & No \\
\hline OCCUPATION (55) & No & No & Yes & Yes & Yes \\
\hline $\operatorname{INDUSTRY}(20)$ & No & No & No & Yes & No \\
\hline FIRM FIXED EFFECT (100) & No & No & No & No & Yes \\
\hline Number of workers & 41290 & 41290 & 41290 & 41290 & 41290 \\
\hline \multicolumn{6}{|l|}{ Subsample "tenure max. 2 years" } \\
\hline FTC & $\begin{array}{l}-0.3227^{* * *} \\
(0.00940)\end{array}$ & $\begin{array}{l}-0.2155^{* * *} \\
(0.00715)\end{array}$ & $\begin{array}{l}-0.1688^{* * *} \\
(0.00622)\end{array}$ & $\begin{array}{l}-0.1644^{* * *} \\
(0.00556)\end{array}$ & $\begin{array}{l}-0.1667^{* * *} \\
(0.00419)\end{array}$ \\
\hline Worker characteristics & No & Yes & Yes & Yes & Yes \\
\hline Firm characteristics & No & No & No & Yes & No \\
\hline OCCUPATION (55) & No & No & Yes & Yes & Yes \\
\hline $\operatorname{INDUSTRY}(27)$ & No & No & No & Yes & No \\
\hline FIRM FIXED EFFECT (9752) & No & No & No & No & Yes \\
\hline Number of workers & 163935 & 163935 & 163935 & 163935 & 163935 \\
\hline \multicolumn{6}{|l|}{ Subsample "tenure max. 6 years" } \\
\hline FTC & $\begin{array}{l}-0.3157^{* * *} \\
(0.00765)\end{array}$ & $\begin{array}{l}-0.1714^{* * *} \\
(0.00597)\end{array}$ & $\begin{array}{l}-0.1376^{* * *} \\
(0.00524)\end{array}$ & $\begin{array}{l}-0.1368^{* * *} \\
(0.00484)\end{array}$ & $\begin{array}{l}-0.1206^{* * *} \\
(0.00313)\end{array}$ \\
\hline Worker characteristics & No & Yes & Yes & Yes & Yes \\
\hline Firm characteristics & No & No & No & Yes & No \\
\hline OCCUPATION (55) & No & No & Yes & Yes & Yes \\
\hline $\operatorname{INDUSTRY}(27)$ & No & No & No & Yes & No \\
\hline FIRM FIXED EFFECT (9912) & No & No & No & No & Yes \\
\hline Number of workers & 363750 & 363750 & 363750 & 363750 & 363750 \\
\hline
\end{tabular}

Notes: Ordinary least squares regressions for log hourly wages, specifications as in Table 2. Robust standard errors clustered at the firm-level in parentheses. Coefficients are significant at ${ }^{*} p<0.05,{ }^{* *} p<0.01$, and ${ }^{* * *} p<0.001$

Source: German Structure of Earnings Survey 2006

ture of Earnings Survey 2006) to estimate the wage differentials between workers with FTCs and with permanent contracts. Mean wage differentials and wage differentials across the wage distribution are significantly negative to the disadvantage of workers with FTCs. Worker characteristics account for about half of the unconditional mean wage differential. The wage disadvantage of workers with FTCs is further significantly reduced by the inclusion of occupation and firm fixed effects. Quantile regressions have additionally shown that the wage differential is larger at the lower tail of the wage distribution but still significant in the middle and upper parts of the wage distribution. Overall, the findings show neither any evidence for compensating wage differentials nor evidence for equal pay, despite legislation on the latter. Due to the cross section nature of the Ger- man Structure of Earnings Survey, no worker fixed effects could be taken into account, which might be another important source of omitted variable bias (Mertens and McGinnity 2004) than analyzed in this paper, which has explicitly dealt with firm heterogeneity. Therefore, a panel design of the German Structure of Earnings Survey would be welcomed that allows the inclusion of firm and worker fixed effects in regression analyses.

\section{Executive summary}

From an empirical perspective, it is well established that workers with fixed-term contracts (FTCs) earn on average significant lower wages than workers with permanent 
Table 6 Wage differentials between workers with FTCs and permanent contracts across the wage distribution with firm fixed effects for wage levels (quantile regressions, specification (5)) for subsamples

\begin{tabular}{|c|c|c|c|c|c|c|c|}
\hline & $5 \%$ & $10 \%$ & $25 \%$ & $50 \%$ & $75 \%$ & $90 \%$ & $95 \%$ \\
\hline \multicolumn{8}{|l|}{ Subsample "large firms" } \\
\hline \multirow[t]{2}{*}{ FTC } & $-0.1466^{* * *}$ & $-0.1015^{* * *}$ & $-0.0748^{* * *}$ & $-0.0708^{* * *}$ & $-0.0694^{* * *}$ & $-0.0784^{* * *}$ & $-0.0992^{* * *}$ \\
\hline & $(0.00588)$ & $(0.00419)$ & $(0.00354)$ & $(0.00357)$ & $(0.00401)$ & $(0.00625)$ & $(0.01050)$ \\
\hline Worker characteristics & Yes & Yes & Yes & Yes & Yes & Yes & Yes \\
\hline Firm characteristics & No & No & No & No & No & No & No \\
\hline OCCUPATION (55) & Yes & Yes & Yes & Yes & Yes & Yes & Yes \\
\hline INDUSTRY $(20)$ & No & No & No & No & No & No & No \\
\hline FIRM FIXED EFFECT (100) & Yes & Yes & Yes & Yes & Yes & Yes & Yes \\
\hline Number of workers & 41290 & 41290 & 41290 & 41290 & 41290 & 41290 & 41290 \\
\hline \multicolumn{8}{|l|}{ Subsample "tenure max. 2 years" } \\
\hline \multirow[t]{2}{*}{ FTC } & $-0.1623^{* * *}$ & $-0.1356^{* * *}$ & $-0.1242^{* * *}$ & $-0.1349^{* * *}$ & $-0.1540^{* * *}$ & $-0.1791^{* * *}$ & $-0.1922^{* * *}$ \\
\hline & $(0.00334)$ & $(0.00213)$ & $(0.00143)$ & $(0.00126)$ & $(0.00166)$ & $(0.00236)$ & $(0.00360)$ \\
\hline Worker characteristics & Yes & Yes & Yes & Yes & Yes & Yes & Yes \\
\hline Firm characteristics & No & No & No & No & No & No & No \\
\hline OCCUPATION (55) & Yes & Yes & Yes & Yes & Yes & Yes & Yes \\
\hline $\operatorname{INDUSTRY}(27)$ & No & No & No & No & No & No & No \\
\hline FIRM FIXED EFFECT (9752) & Yes & Yes & Yes & Yes & Yes & Yes & Yes \\
\hline Number of workers & 163935 & 163935 & 163935 & 163935 & 163935 & 163935 & 163935 \\
\hline \multicolumn{8}{|l|}{ Subsample "tenure max. 6 years" } \\
\hline \multirow[t]{2}{*}{ FTC } & $-0.1565^{* * *}$ & $-0.1144^{* * *}$ & $-0.0898^{* * *}$ & $-0.0885^{* * *}$ & $-0.0992^{* * *}$ & $-0.1138^{* * *}$ & $-0.1247^{* * *}$ \\
\hline & $(0.00209)$ & $(0.00155)$ & $(0.00109)$ & $(0.00100)$ & $(0.00137)$ & $(0.00207)$ & $(0.00318)$ \\
\hline Worker characteristics & Yes & Yes & Yes & Yes & Yes & Yes & Yes \\
\hline Firm characteristics & No & No & No & No & No & No & No \\
\hline OCCUPATION (55) & Yes & Yes & Yes & Yes & Yes & Yes & Yes \\
\hline INDUSTRY (27) & No & No & No & No & No & No & No \\
\hline FIRM FIXED EFFECT (9912) & Yes & Yes & Yes & Yes & Yes & Yes & Yes \\
\hline Number of workers & 363750 & 363750 & 363750 & 363750 & 363750 & 363750 & 363750 \\
\hline
\end{tabular}

Notes: Quantile regressions for log hourly wages, specification (5) as in Table 4. Standard errors in parentheses. Coefficients are significant at ${ }^{*} p<0.05,{ }^{* *} p<0.01$, and ${ }^{* * *} p<0.001$

Source: German Structure of Earnings Survey 2006

contracts. Some studies also explore the wage differentials across the wage distribution and find larger than average wage differentials at the lower tail of the wage distribution and low but still significant wage disadvantages for FTCs at the top of the wage distribution. Due to data limitations previous studies, at least for Germany, suffer from the absence of the information about a worker's workplace so that within-firm wage differentials cannot be estimated. Consequently, the estimated wage differentials might suffer from an omitted variable bias due to unobserved firm characteris- tics. In order to deal with this issue, I use an administrative linked employer-employee data set from the German Federal Statistical Office-the German Structure of Earnings Survey 2006. Due to its large sample size, the German Structure of Earnings Survey is also more suitable to analyze the wage differentials across the wage distribution than smaller survey data sets.

The main findings of my econometric analysis, in which I estimate earnings functions, are as follows. Mean wage differentials and wage differentials across the wage distribu- 
tion are significantly negative to the disadvantage of workers with FTCs. Worker characteristics account for about half of the unconditional mean wage differential. The wage disadvantage of workers with FTCs is further significantly reduced to approximately ten percent by the inclusion of occupation and firm fixed effects. Quantile regressions additionally show that the wage differential is larger at the lower tail of the wage distribution but still significant in the middle and upper parts of the wage distribution. Overall, the findings show neither any evidence for compensating wage differentials nor evidence for equal pay, despite legislation on the latter (,Gesetz über Teilzeitarbeit und befristete Arbeitsverträge“").

\section{Kurzfassung}

Ein empirisch gut belegter Befund ist, dass Arbeitnehmer mit befristeten Arbeitsverträgen im Durchschnitt signifikant geringere Einkommen verdienen als Arbeitnehmer mit unbefristeten Arbeitsverträgen. Einige Studien untersuchen ferner die Lohndifferentiale über die Lohnverteilung und finden überdurchschnittliche Lohnnachteile am unteren Ende der Lohnverteilung and unterdurchschnittliche aber immer noch signifikante Lohnnachteile für Arbeitnehmer mit befristeten Arbeitsverträgen am oberen Ende der Lohnverteilung. Eine Beschränkung der genutzten Daten in bisherigen Studien (zumindest für Deutschland) ist das Fehlen von Betriebsindikatoren für die einzelnen Arbeitnehmer, so dass keine Lohndifferentiale innerhalb von Firmen geschätzt werden konnten. Daher könnten die geschätzten Lohndifferentiale einer Verzerrung durch unterdrückte Variablen (,omitted variable bias") aufgrund unbeobachteter Firmeneigenschaften unterliegen. Um dieses Problem explizit zu berücksichtigen, nutze ich administrative verbundene

Arbeitgeber-Arbeitnehmer-Daten des Statistischen Bundesamtes - die Verdienststrukturerhebung 2006. Zudem ist die Verdienststrukturerhebung aufgrund ihrer großen Anzahl an Beobachtungen besser geeignet für die Untersuchung der Lohndifferentiale über die Lohnverteilung als kleinere Umfragedatensätze.

Die wesentlichen Ergebnisse meiner ökonometrischen Analyse, in der ich Einkommensfunktionen schätze, sind wie folgt. Die durchschnittlichen Lohndifferentiale und die Lohndifferentiale über die gesamte Lohnverteilung sind signifikant negativ zu Ungunsten von Arbeitnehmern mit befristeten Arbeitsverträgen. Unterschiede in den persönliche Eigenschaften der Arbeitnehmer erklären etwa die Hälfte der unbedingten mittleren Lohndifferenz. Die geschätzten Lohnnachteile von Arbeitnehmern mit befristeten Arbeitsverträgen sinken durch die Aufnahme von Berufen und fixen Firmeneffekten weiter auf ungefähr zehn Prozent. Quantilsregressionen zeigen ferner, dass der Lohnnachteil zwar am größten am unteren Ende der Lohnverteilung aber immer noch signifikant im mittleren und oberen Bereich der Lohnverteilung ist. Insgesamt sind die Ergebnisse weder im Einklang mit der Theorie der kompensierenden Lohndifferentiale noch mit dem Grundsatz der gleichen Entlohnung, obwohl letzteres gesetzlich verankert ist („,Gesetz über Teilzeitarbeit und befristete Arbeitsverträge").

Acknowledgements I thank Bernd Fitzenberger, Joachim Wagner, and two referees for their comments.

\section{Appendix}

Table 7 Relative wage differentials between workers with FTCs and permanent contracts (OLS regressions, complete sample) with different transformation approaches

\begin{tabular}{lllll}
\hline & $(1)$ & $(2)$ & (3) & (4) \\
\hline Estimated differential $\log \operatorname{WAGES}(\beta)$ & -0.4061 & -0.1932 & -0.1575 & -0.1529 \\
$\begin{array}{l}\text { Transformation not adjusted for } \\
\text { heteroskedasticity: } 100(\exp (\beta) Q-1)\end{array}$ & $-33.38 \%$ & $-17.57 \%$ & $-14.57 \%$ & $-14.18 \%$ \\
$\begin{array}{l}\text { Transformation adjusted for } \\
\text { heteroskedasticity: }\left(\exp (\beta) Q_{N}-1\right)\end{array}$ & $-32.10 \%$ & $-15.25 \%$ & $-11.70 \%$ & $-11.26 \%$ \\
$\begin{array}{l}\text { Transformation adjusted for } \\
\text { heteroskedasticity: }\left(\exp (\beta) Q_{T}-1\right)\end{array}$ & $-32.23 \%$ & $-15.41 \%$ & $-11.87 \%$ & $-11.92 \%$ \\
$Q_{N}=\exp \left(0.5\left(\hat{\sigma}_{F T C=1}-\hat{\sigma}_{F T C=0}\right)\right)$ & 1.0191 & $1.0283 \%$ \\
$Q_{T}=\left(1+0.5 \hat{\sigma}_{F T C=1}\right) /\left(1+0.5 \hat{\sigma}_{F T C=0}\right)$ & 1.0172 & 1.0262 & 1.0337 & 1.0340 \\
\hline
\end{tabular}

Notes: Based on results of ordinary least squares regressions for log hourly wages (Table 2)

Source: German Structure of Earnings Survey 2006 


\section{References}

Boockmann, B., Hagen, T.: Fixed-term contracts as sorting mechanisms: evidence from job durations in West Germany. Labour Econ. 15, 984-1005 (2008)

Booth, A.L., Francesconi, M., Frank, J.: Temporary jobs: stepping stones or dead ends? Econ. J. (Lond.) 112, F189-F213 (2002)

Brown, S., Sessions, J.G.: Earnings, education, and fixed-term contracts. Scott. J. Polit. Econ. 50, 492-506 (2003)

Brown, S., Sessions, J.G.: Employee attitudes, earnings, and fixed-term contracts: international evidence. Rev. World Econ. 141, 296-317 (2005)

Gebel, M., Giesecke, J.: Labour market flexibility and inequality: the changing risk patterns of temporary employment in West Germany. Z. Arbeitsmarktfoschung 42, 234-251 (2009)

Güell, M., Petrongolo, B.: How binding are legal limits? Transitions from temporary to permanent work in Spain. Labour Econ. 14, 153-183 (2007)

Hafner, H.-P., Lenz, R.: The German Structure of Earnings Survey: methodology, data access and research potential. Schmollers Jahrb. Wirtsch.- Soz.wiss. 128, 489-500 (2008)

Hagen, T.: Do temporary workers receive risk premiums? Assessing the wage effects of fixed-term contracts in West Germany by a matching estimator compared with parametric approaches. Labour 16, 667-705 (2002)

Leontaridi, M.R.: Segmented labour markets: theory and evidence. J. Econ. Surv. 12, 63-101 (1998)

Mertens, A., McGinnity, F.: Wages and wage growth of fixed-term workers in East and West Germany. Appl. Econ. Q. 50, 139-163 (2004)

Mertens, A., McGinnity, F.: A "two-tier" labour market for fixedterm jobs? Evaluating evidence from West Germany using quan- tile regression. Schmollers Jahrb. Wirtsch.- Soz.wiss. 125, 75-85 (2005)

Mertens, A., Gash, V., McGinnity, F.: The cost of flexibility at the margin. Comparing the wage penalty for fixed-term contracts in Germany and Spain using quantile regression. Labour 21, 637-666 (2007)

OECD: Employment Outlook 2002. OECD, Paris (2002)

Pfeifer, C.: Fixed-term contracts and employment adjustment-An empirical test of the core-periphery hypothesis using German establishment data. Econ. Rec. 85, 92-107 (2009)

Rebitzer, J.B., Taylor, L.J.: A model of dual labor markets when product demand is uncertain. Q. J. Econ. 106, 1373-1383 (1991)

Saint-Paul, G.: Dynamic labor demand with dual labor markets. Econ. Lett. 36, 219-222 (1991)

Taubman, P., Wachter, M.L.: Segmented Labor Markets. Handbook of Labor Economics, vol. 2, pp. 1183-1217 (1986)

Winkelmann, R.: Zur korrekten Interpretation der Ergebnisse einer log-linearen Regression bei Heteroskedastie. Jahrbüch. Nationalökonomie Statist. 221, 418-431 (2001)

Christian Pfeifer studied economics and management at Leibniz University Hannover, Germany, and Maastricht University, Netherlands. He received his Diploma (Master equivalent) in 2003 and doctoral degree in 2007 from Leibniz University Hannover. From 2007 to 2009 he was a Post-Doc at Leibniz University Hannover and University of California Berkeley. Since September 2009 he is Professor (W1) of Economics at Leuphana University Lüneburg. His research focus is on empirical labour and personnel economics. 